\title{
Sjúkratilfelli. Fyrirferð í sáðblöðru hjá sjúklingi með eitt nýra
}

\section{Margrét Brands Viktorsdóttir} kandídat $^{12}$

\section{Eiríkur Jónsson}

pvagfæraskurðlæknir

\section{Hildur Einarsdóttir \\ röntgenlæknir ${ }^{4}$}

Lykilorð: karlmenn sáđblöđrublađra, nýrnavísisleysi.

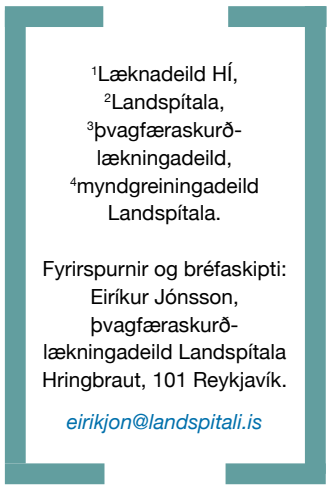

\section{Ágrip}

Hér er rakin sjúkrasaga tuttugu og fimm ára karlmanns sem greindist með blöðrur á hægri sáðblöðru. Hann fæddist með nýrnavísisleysi sömu megin og leitaði á bráðamóttöku eftir að hafa verið með vaxandi verk í endaparmi og við sáđlát í prjá mánuði. Hægri sáđblaðran var fjarlægð í opinni aðgerð og varð sjúklingurinn einkennalaus á eftir.

\section{Sjúkratilfelli}

Tuttugu og fimm ára hraustur karlmaður leitaði á bráðamóttöku eftir að hafa verið um priggja mánaða skeið með vaxandi verk í endaparmi með verkjaleiðni yfir spangarsvæði og fram 1 getnaðarlim. Hann lýsti stöðugri hægðapörf og verkjum við hægðalosun sem og við sáðlát en hafði ekki einkenni frá pvagfærum. Maðurinn fæddist með eitt nýra og hafði farið í endurísetningu á vinstri pvagleiðara sem barn vegna bakflæðis. Við endaparmspreifingu reyndist hann vera með auma mjúka fyrirferð hægra megin og ofan til við blöðruhálskirtilinn. Pvagskoðun var eðlileg sem og stutt ristilspeglun. Fengin var segulómun af kviðar- og grindarholi sem sýndi stækkun á vinstra nýra en hægra nýra sást ekki. Vinstri sáðblaðra hafði eðlilegt útlit en á hægri sáðblöðru sáust margar og fyrirferðarmiklar blöðrur sem teygðu sig upp á miðjan spjaldhrygg. Stærsta blaðran mælist 2,6 x 2,1 x 7,2 cm (mynd 1).

Sjúklingur var tekinn til aðgerðar par sem hægri sáðblaðra var fjarlægð. Strengur eins og pvagleiðari gekk upp úr sáðblöðrunni (mynd 2). Aðgerð gekk vel og mánuði eftir hana var sjúklingur einkennalaus. Vefjagreining sýndi fram á útvíkkaða sáðblöðru ásamt hluta af sáðrás og leifar af miðnýrnarás (mesonephric duct).

\section{Umræða}

Blöðrur á sáðblöðrum geta verið meðfæddar eða áunnar. Раð sem einkennir meðfæddar blöðrur á sáðblöðrum eru tengsl peirra við aðra meðfædda galla á pvag- og kynfærum, eins og nýrnavísisleysi sömu megin (ipsilateral renal agenesis), nýrnamisvöxt (renal dysplasia) eða pvagleiðaraleif (rudimentary ureter). Meðfæddar blöðrur á sáðblöðrum tengjast nýrnavísisleysi

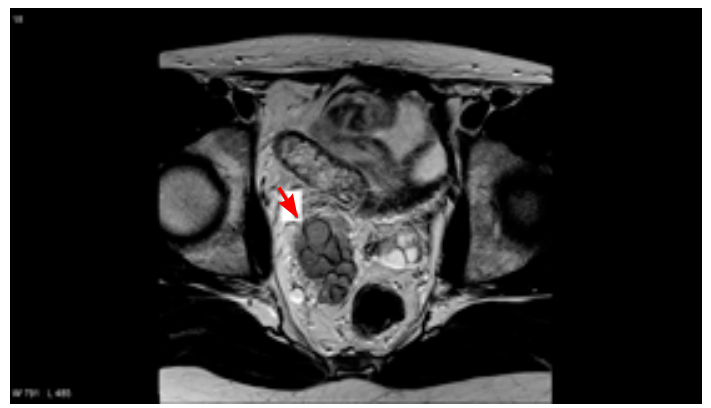

Mynd 1. Vinstri sádblađra hefur eđlilegt útlit en á hægri sáðblöðru eru margar og fyrirferðarmiklar blödrur (ör). Segulómmynd tekin á Landspitala Hringbraut.

sömu megin í 68\% tilfella og leifar af pvagleiðara hafa fundist í um 13\% pessara sjúklinga. ${ }^{1}$ Áunnar blöðrur á sáðblöðrur geta myndast í tengslum við góðkynja stækkun á blöðruhálskirtli, aðgerð á blöðruhálskirtli eða bólgu í sáðfallsrás og pá oftast sem afleiðing af öflugri pvagfærasýkingu. ${ }^{2}$

Blöðrur á sáðblöðrum í tengslum við nýrnavísisleysi sömu megin er afar sjaldgæfur sjúkdómur. Fyrsta tilfellinu var lýst árið 1914 af Zinner. ${ }^{2}$ Síðan pá hefur um 200 slíkum tilfellum

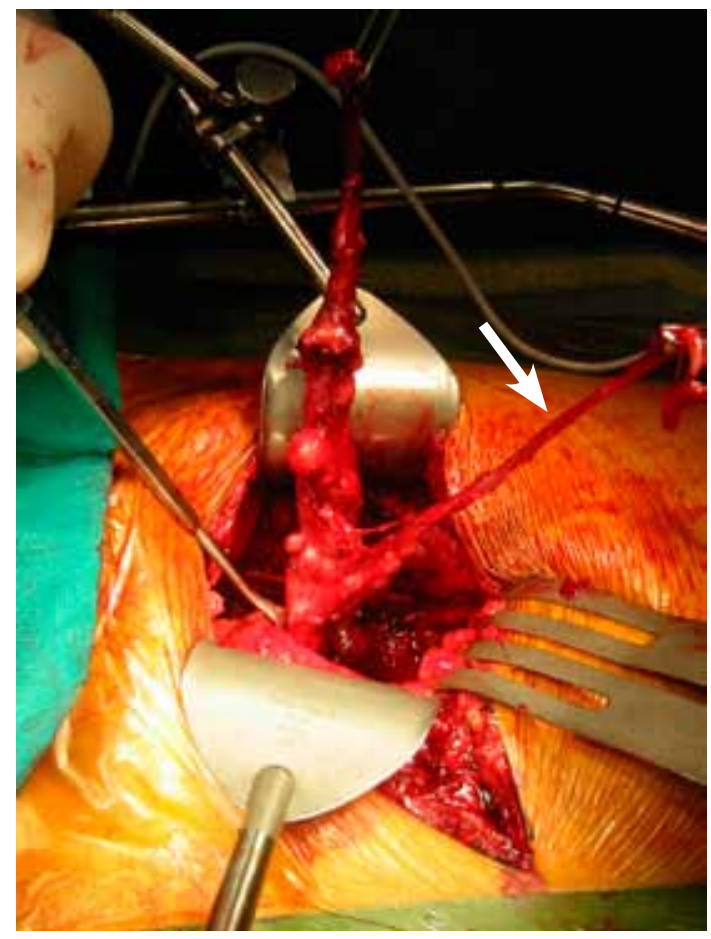

Mynd 2. Mynd tekin í aðgerð. Sýnir hægri sáðblöðru sem á eru margar litlar blöðrur. Einnig sést leif af pvagleiðara (ör). Myndina tók Eiríkur Jónsson pvagfæraskurðlæknir. 
í heiminum verið lýst með tilkomu betri greiningartækni eins og tölvusneiðmyndun og segulómun..$^{3,4}$ Blöðrur á sáðblöðrum greinast oftast hjá sjúklingum sem eru á milli tvítugs og prítugs. Blöðrur sem eru minni en fimm sentímetrar geta verið einkennalausar og greinast pá oftast fyrir tilviljun. ${ }^{5}$ Stærri blöðrur valda oftar einkennum. Algeng einkenni eru verkir í kviðarholi, grindarholi eða spöng, verkir við sáðlát, verkir við pvaglát, tíð pvaglát, blóðmiga, pvagfærasýkingar eða ófrjósemi. ${ }^{3,5-7}$ Pessi einkenni líkjast mjög algengum einkennum blöðruhálskirtilsbólgu og pví getur greining verið torveld og dregist á langinn. Preifing um endaparm getur vakið grun um petta vandamál en myndgreining er framkvæmd með ómun um endaparm, sneiðmyndatöku eða segulómun. Sú síðastnefnda gefur pó nákvæmustu greininguna. ${ }^{5,8}$

Tengslin milli blaðra á sáðblöðrum og nýrnavísisleysis sömu megin er hægt að skýra vegna sameiginlegs fósturfræðilegs uppruna. Pvagleiðarasproti (ureteral bud) myndast frá afturhluta miðnýrnarásar (mesonephric duct) og virkjar sérhæfingu á miðnýranu (mesonephros) sem verður svo að hinu endanlega nýra (metanephros). Miðnýrnarásin sérhæfist svo î eistnalyppu, sáðrás, sáðfallsrás og sáðblöðru. ${ }^{9}$ Eðlileg myndun á nýra á fósturstigi er pví háð aðleiðslu pvagleiðarasprotans og miðnýrnarásarinnar. Vanmyndun á afturhluta miðnýrnarásar leiðir til pess að pvagleiðarasproti myndast ekki. Раð veldur nýrnavísisleysi peim megin og lokun á sáðfallsrás sem leiðir til pess að sáðblaðran stíflast, seyti safnast fyrir og blöðrur myndast.

Meðferð er ópörf nema blöðrurnar valdi einkennum. ${ }^{3}$ Lengi vel hefur opin aðgerð verið algengasta meðferðarformið með 100\% árangurshlutfalli, en vegna staðsetningar sáðblaðranna djúpt í grindarholi er aukin hætta á fylgikvillum eins og taugaskaða eða skaða á nærliggjandi líffærum, aðallega endaparmi, pvagblöðru eða pvagleiðara. ${ }^{1}$ Tæming á pessum blöðrum með pví að stinga á peim um endaparm er sjaldan árangursrík, með 30\% árangurshlutfalli, og tengist hárri endurkomutíðni og sýkingum. ${ }^{1,6-7}$ Í seinni tíð er í auknum mæli farið að fjarlægja blöðrur af sáðblöðrum gegnum kviðsjá. ${ }^{4,6}$

\section{Lokaoro}

Blöðrur á sáðblöðru ásamt nýrnavísisleysi sömu megin er sjaldgæfur meðfæddur galli. Einkenni geta verið margvísleg, líkjast oft einkennum blöðruhálskirtilsbólgu og pví getur rétt greining tafist. Segulómun af grindarholi er ákjósanleg greiningaraðferð og brottnám á sáđblöðru er líkleg til pess að uppræta einkenni.

\section{Heimildir}

1. van den Ouden D, Blom JH, Bangma C, et al. Diagnosis and management of seminal vesicle cysts associated with ipsilateral renal agenesis: a pooled analysis of 52 cases. Eur Urol 1998; 33: 433-40.

2. Zinner A. Ein fall von intravesikaler samenblasencyste. Wien Med Wochenschr 1914; 64: 605-9.

3. Gozen AS, Alagol B. Endoscopic management of seminalvesical cyst with right renal agenesis causing acute urinary retention: Case report. J Endourol 2006; 20: 919-22.

4. Han P, Dong $\mathrm{Q}$, Shi $\mathrm{M}$, et al. Seminal vesicle cyst and ipsilateral renal agenesis: laparoscopic approach. Arch Androl 2007; 53: 285-8

5. Livingston L, Larsen CR. Seminal Vesicle Cyst with Ipsilateral Renal Agenesis. Am J Roentgenol 2000; 175: 17780.

6. Liatsikos EN, Lee B, Filos KS, et al. Congenital seminal vesicle cyst and coexisting renal agenesis: laparoscopic approach. Urology 2004; 63: 584-6.

7. Seo IY, Kim HS, Rim JS. Congenital Seminal Vesicle Cyst Associated with Ipsilateral Renal Agenesis. Yonsei Med J 2009; 50: 560-3.

8. Pace G, Galatioto GP, Gualà L, et al. Ejaculatory duct obstruction caused by a right giant seminal vesicle with an ipsilateral upper urinary tract agenesia: an embryologic malformation. Fertil Steril 2008; 89: 390-4.

9. Sadler T. Langman's Medical Embryology. 8th Edition ed. Lippincott Williams \& Wilkins, Baltimore 2000.

\section{Case report: Seminal vesicle cyst with ipsilateral renal agenesis}

We describe a case of right seminal vesicle cyst with ipsilateral renal agenesis in a 25 year old male. The cyst caused severe pain syndrome with progressive perineal pain and pain on defecation and ejaculation. The cyst was surgically removed and the patient became asymtomatic.

Viktorsdottir MB, Jonsson E, Einarsdottir $H$.

Case report: Seminal vesicle cyst with ipsilateral renal agenesis. Icel Med J 2010; 96: 619-20

Correspondence: Eiríkur Jónsson, eirikjon@landspitali.is

Key words: Men, seminal vesicle cysts, ipsilateral renal agenesis. 